\title{
TINJAUAN TEOLOGIS KONSEP BANGSA ISRAEL TENTANG KEMATIAN
}

\author{
David Susilo Pranoto
}

davidsusilopranoto@sttab.ac.id

\begin{abstract}
The concept of death is something that is often questioned by humans. Because no human being has been able to provide strong evidence of what happened after death. Therefore this question also needs to be answered in the light of the Christian faith. The rationale for discussing death is the Bible. But it must be realized that the Bible is also present in the cultural context and traditions of the nation of Israel. So to get the principle or meaning needed is also an assessment of the context and principle of death of the people of Israel. Theological review is needed so as not to get caught up in Judaism in understanding the concept of death. Therefore, through this paper will explain the theological review of the concept of the nation of Israel about death.
\end{abstract}

Keywords: $\quad$ Overview, Theological, Israel, Death.

Abstraksi: $\quad$ Konsep kematian adalah hal yang sering dipertanyakan oleh manusia. Karena belum ada manusia yang mampu memberikan bukti kuat apa yang tejadi setelah kematian. Oleh karena itu pertanyaan tersebut juga perlu dijawab dalam terang iman Kristen. Dasar pemikiran untuk membahas tentang kematian adalah Alkitab. Namun perlu disadari bahwa Alkitab juga hadir dalam konteks budaya dan tradisi bangsa Israel. Sehingga untuk mendapatkan prinsip atau makna dibutuhkan juga pengkajian konteks dan prinsip kematian dari umat Israel. Tinjauan teologis dibutuhkam agar tidak terjebak dalam Yudaisme dalam memahami konsep kematian. Oleh karena itu melalui tulisan ini akan memaparkan tentang tinjauan teologis konsep Bangsa Israeltentang kematian.

Kata Kunci: Tinjauan, Teologis, Bangsa Israel, Kematian.

\section{PENDAHULUAN}

Ibadat orang mati, yang merupakan sebuah ciri masyarakat Israel, merujuk pada ritual-ritual yang dilakukan oleh mereka yang masih hidup untuk kepentingan anggota keluarga yang telah mati. Di Israel kuno "Yahwisme resmi" yang mengecam segala bentuk kontak dengan orang mati, sementara "agama populer,", dibawah pengaruh praktik orang Kanaan, mengijinkan pemujaan nenek moyang atau leluhur. Dalam agama rakyat, ibadat orang mati adalah cara yang umum untuk memperoleh berkah dari orang mati atau untuk menenangkan mereka. Melengkapi orang mati dengan barang-barang pribadi mengimplikasikan bahwa barang-barang ini akan berguna pada kehidupan sesudah kematian. Memelihara orang mati adalah suatu cara bagi anggota keluarga untuk mempertahankan hubungan antara satu generasi dengan generasi berikutnya. Dengan kata 
lain, ibadat orang mati menekankan keberlangsungan kekerabatan. ${ }^{1}$ dapat diartikan bahwa bangsa Israel sangat memelihara hubungan dengan generasi-generasi yang selanjutnya.

Orang Israel mengembangkan ide mereka sendiri mengenai orang mati dari konsep-konsep yang berkaitan dengan kebudayaan Mesopotamia dan Kanaan. Meskipun kematian menandai akhir kehidupan di bumi, si orang mati tetap hidup sebagai arwah di Syeol atau didalam kuburan keluarga. Dengan kata lain kematian bukanlah pelenyapan, melainkan transisi ke jenis keberadaan yang lain di Syeol. Digunakan 66 kali di dalam Alkitab "Syeol" tidak ditemukan dalam bahasa semitik lainnya. Etimologinya tidaklah pasti, tetapi mungkin kata ini berkaitan dengan istilah sa'al "bertanya", dalam artian bertanya kepada roh orang mati. Beberapa orang mengira bahwa Syeol aslinya berarti tempat interogasi. Istilah-istilah Ibrani lainnya yang menunjuk pada tempat tinggal orang mati adalah bor dan sakhat keduanya diterjemahkan dengan "lubang".

Syeol bukanlah sebuah tempat penghukuman, dalam arti siksaan dan deraan; sebaliknya Syeol menandakan keterbuangan dari Allah, yang pada dirinya sendiri merupakan nasib yang pantas disesalkan. Dalam kepercayaan umat Israel, hakikat dari kehidupan adalah kemampuan untuk memuliakan Allah; bagi orang mati di Syeol memuliakan Allah adalah tidak mungkin karena orang mati tidak mempunyai kontak dengan kehadiran ilahi. Dalam kata-kata Raja Hiskia setelah sembuh dari sakitnya, sebab dunia orang mati (Syeol) tidak dapat mengucap syukur kepada-Mu, dan maut tidak dapat memuji-muji Engkau; orang-orang yang turun kedalam liang kubur tidak menanti-nanti akan kesetiaan-Mu (Yes 38:18). ${ }^{3}$

Penulis berpendapat bahwa pemahaman Bangsa Israel mengenai tempat orang yang sudah meninggal adalah meskipun seseorang sudah meninggal akan tetapi roh orang mati tetap hidup sebagai arwah di Syeol dimana tempat yang suram dan gelap namun bukan tempat penghukuman. Sejarah pemindahan tulang Yusuf dimulai dari ketika Yusuf meminta tulang-tulangnya di kubur di Kanaan karena keyakinannya bahwa Tuhan akan memberikan mereka sebuah tanah yang dijanjikan dan bahwa Mesir bukanlah tanah perjanjian itu tetapi Kanaan. Paling tidak membawa kontribusi dalam perjalanan di Padang gurun yang penuh tantangan. Firman Tuhan yang membuktikan bahwa pemindahan tulang Yusuf adalah permintaan Yusuf dan bukti janji Allah kepada Yusuf bahwa Allah akan memelihara bangsa Israel diantaranya, Kel 13:19 "Musa membawa tulang-tulang Yusuf,

\footnotetext{
${ }^{1}$ Philip J King, kehidupan orang Israel Alkitabiah, (Jakarta: BPK Gunung Mulia, 2010), 430

${ }^{2}$ Ibid,... 428

${ }^{3}$ Ibid., 429
} 
sebab tadinya Yusuf telah menyuruh anak-anak Israel bersumpah dengan sungguhsungguh: "Allah tentu akan mengindahkan kamu, maka kamu harus membawa tulangtulangku dari sini." ${ }^{4}$ ini merupakan bukti iman Yusuf dan janji Allah bahwa Allah akan memelihara bangsa Israel keluar dari tanah Mesir.

Setelah kematian Yakub, ayahnya, Yusuf hidup selama 53 tahun lagi di Mesir, maka ia mengakhiri kehidupannya pada usia 110 tahun (Kej 50: 26). Jadi "zaman bapabapa leluhur" berakhir dengan kematian Yusuf. Tidak seperti pemakaman Yakub yang mewah dan dikuburkan di Kanaan, jasad Yusuf dirempah-rempahi dan ditaruh dalam peti mati sebagai mumi di Mesir (Kej 50: 22-26). Dan setelah waktunya tiba akan dibawa sesuai permintaan Yusuf.

Di 1806 SM, 276 tahun setelah perjanjian suluh dibuat, Yusuf membuat keturunannya bersumpah bahwa mereka pasti akan membawa tulangnya di sana (Kej 50:25). Permintaan Yusuf demikian adalah karena dia telah percaya dengan teguh tanpa ada sedikit pun keraguan akan janji Allah mengenai Kanaan, tanah janji. ${ }^{5}$ Berikutnya ia memberikan tulang belulangnya (Kej 50:25, Ibr 22:22). Tidak seperti Yakub ayahnya yang meminta ayahnya agar jasadnya segera dibawa dan dikuburkan di Kanaan, Yusuf memerintahkan agar tulang-belulangnya dibawa keluar dari Mesir ketika Allah memperlihatkan Israel. Yusuf tidak ingin hanya dia yang lebih dulu dikuburkan di Kanaan, melainkan dia sungguh-sungguh ingin turut serta dalam eksodus Israel dan memasuki Kanaan bersama-sama dengan bangsanya.

Permintaan Yusuf kepada keturunannya untuk membawa tulang-tulangnya ketanah Kanaan, didasarkan pada keyakinan imannya. Tuhan telah berjanji kepada Abraham untuk memberikan tanah Kanaan. Bahkan Tuhan telah memberitahukan Abraham, bahwa keturunannya akan diperbudak selama 400 tahun. Setelah itu, Tuhan berjanji akan membawa mereka kembali ke tanah yang telah dijanjikan. ${ }^{6}$

Pemindahan tulang juga dilakukan oleh keluarga Yusuf ketika Yusuf sendiri telah mati. Baik mayat Yusuf maupun mayat bapaknya dirempah-rempahi sesuai dengan kebiasaan Mesir (K ej 50:2, 3, 26), dan mayat Yusuf ditaruh dalam peti mati di Mesir petimati. Umur Yusuf waktu ia meninggal ialah 110 tahun. Ini punya makna, karena umur 110 adalah yang paling ideal bagi orang Mesir, dan mereka menganggapnya berkat ilahi. ${ }^{7}$ Dalam

\footnotetext{
${ }^{4}$ Alkitab.

${ }^{5}$ Abraham Park, Pertemuan Yang Terlupakan (Depok: Yayasan Damai Sejahtera, 2017),

${ }^{6}$ Hendry James Silalahi, Pandangan Injil terhadap Upacara Adat Batak, (Sumatra Utara: Yayasan Karya Misi Kasih, 2004), 167.

${ }^{7}$ LAI, Ensiklopedi Masa Kini Jilid II, (Jakarta: Yayasan Bina Kasih, 1997 ), 642.
} 
tradisi ini, keluarga Yusuf tidaklah melakukan dengan sengaja atau merupakan tradisi dari nenek moyang namun karena perjanjian dan bukti iman Yusuf.

Yusuf mencapai umur 110 tahun yang menurut bangsa Mesir adalah umur istimewa, oleh karena umur 110 tahun lebih dari satu abad. Ia masih melihat cicit-cicitnya, yaitu cucu anak-anaknya. setelah dirasanya ajalnya telah dekat, disuruhnyalah keluarganya bersumpah, bahwa mereka akan membawa segala tulang-tulangnya dari Mesir, jika mereka pulang kembali ke kanaan. Ini adalah bukti kepercayaan (Ibr 11:22). Dengan itu Yusuf menyatakan kepercayaannya, bahwa bangsa Israel akan pulang dari Mesir ke Kanaan. Mereka akan membawa tulang-tulang Yusuf dan dikuburkan dekat Sikhem. ${ }^{8}$

Dengan demikian penulis berpendapat bahwa pemindahan tulang yang dilakukan oleh keluarga Yusuf bukan karena mengikuti tradisi yang ada pada saat itu, namun karena perjanjian dimana Allah akan melawat dan memelihara Bangsa Israel keluar dari tanah Mesir. Dan hal ini tidak memiliki kaitan kepada hal yang berkaitan dengan tradisi yang dilakukan oleh suku Batak dalam memindahkan tulang.

\section{TINJAUAN TEOLOGIS}

Dalam bagian ini akan mengeksegese beberapa ayat penting untuk mendapatkan kajian yang mendalam sehingga dapat memahami Tinjauan Alkitab tentang penggalian tulang (mangokkal holi) dalam tradisi Batak dengan benar.

\section{Tubuh Orang Mati Kembali Menjadi Tanah Dan Roh Kembali Kepada Allah}

Ketika itulah TUHAN Allah membentuk manusia itu dari debu tanah (kej 2:7), dan dibalas pada pengkhotbah 12: 7 yang mengatakan "dan debu kembali menjadi tanah seperti semula dan roh kembali kepada Allah yang" ayat ini menjelaskan asal muasal tubuh manusia yang dibentuk dari debu tanah. Secara harfiah kata הֶֶֶֶֶר (heapar) memiliki arti "debu (noun common atau kata benda yang bersifat umum), yang bersifat mutlak. Sedangkan kata "menjadi tanah" memakai kata עַלדזהָריץ (al-haarets) dengan memakai kasus particle preposition particle article noun common feminine singular absolute, yang artinya earth, land, ground. ${ }^{9}$ Kata "ke, kedalam, ke arah". ${ }^{10}$ Sedangkan kan kata האָרץ (ha-arets) artinya bumi atau tanah.

Berdasarkan kajian di atas penulis menjelaskan bahwa debu itu akan kembali menjadi tanah, atau debu itu akan kembali ke dalam bumi itu dengan kata lain debu itu

\footnotetext{
${ }^{8}$ F.L. Baker, Sejarah Kerajaan Allah, (Jakarta: BPK Gunung Mulia, 2002), 236.

${ }^{9}$ John Joseph owens, Analytical Key Old Testament, (America: Baker Boks House, 1993) 642.

${ }^{10}$ Page H. Kelly, Pengantar Tata Bahasa Ibrani Biblikal, (Surabaya: Momentum, 20013), 36.
} 
akan kembali ke semula menjadi debu tanah itu. Ini menyatakan bahwa manusia yang diciptakan dari debu tanah sewaktu matinya tubuhnya pun akan kembali ke debu tanah.

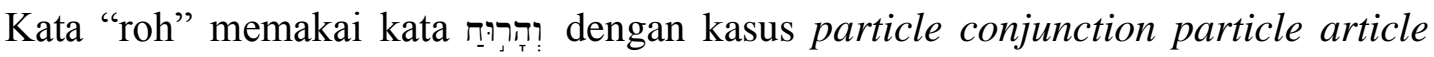
noun common singular absolute (breath, spirit ) atau dalam pengertian nafas, roh. ${ }^{11}$ Kata ini juga dibubuhi dengan kata penghubung yaitu ? (conjungtion) yang artinya "dan", baru disusul dengan partikel $\pi_{T}(h a)$ atau kata penunjuk, yang artinya "itu". Jadi kata ini memiliki arti yaitu, dan roh. Sedangkan kata "kembali" dalam bahasa asli memakai kata תזיו (tasub) dengan kasus verb qal imperfect 3rd person feminine singular (to turn, return) yang artinya kembali. ${ }^{12}$ Merupakan kata kerja yang merupakan sebuah bentuk perbuatan yang belum selesai dan tertuju kepada orang ke-3 tunggal. Berarti kata ini memiliki pengertian, dia akan kembali atau berbalik.

Sedangkan kata "kepada Allah" dalam bahasa asli memakai kata אלידזהאלהים (elhaelohim) dengan memakai kasus particle preposition particle article noun common masculine plural absolute (in to the God) artinya kepada Allah. ${ }^{13}$ Kata ini terdiri dari kata אלהָים "kepada atau bagi”, dan kata penunjuk "ה "itu”. Sedangkan kata "הל depan atau (Elohim) merupakan kata benda jamak "ke-3 pribadi Allah" dan memiliki sifat yang mutlak. Jadi, pengertian dari kata ini yaitu, kepada Allah.

Dan debu kembali menjadi tanah seperti semula, di sini tergambar secara nyata anggapan umum tentang apa yang terjadi setelah manusia mati: tubuh kembali keasalnya (Kej 2:7); dan roh kembali kepada sumbernya (kej 2:7, Ayub 34:14,15 Mzm 104: 29). Manusia berhenti hidup sebagai manusia. ${ }^{14}$ Artinya manusia yang sudah mati telah berhenti hidup sebagai manusia dan ketika matinya akan hidup sebagai roh.

Dapat disimpulkan bahwa tubuh orang yang sudah mati akan kembali menjadi tanah seperti semula, sebagaimana Allah telah menjadikan manusia dari debu tanah, maka tubuh itu akan kembali menjadi tanah. Sedangkan roh orang yang sudah mati akan kembali kepada Allah yang memberikan roh itu, dan memiliki tempat tersendiri. Namun hal ini harus dipahami dalam konteks sebelum kedatangan Tuhan Yesus yang keduakali, karena pada konteks eskatologis akan terjadi kebangkitan daging, sehingga roh akan ada dalam tubuh kemuliaan.

\section{Orang Yang Sudah Mati Tidak Memiliki Upah}

\footnotetext{
${ }^{11}$ John Joseph owens, Analytical Key Old Testament..., 643.

12 Ibid,..643.

${ }^{13}$ Ibid,..643 .

${ }^{14}$ Robert Laurin, The WYCLIFFE Bible commentary, Kitab Pengkhotbah (Malang: Gandum MAS, 2007), 392.
} 
Dalam Pengkhotbah 9:5b menegaskan bahwa orang yang sudah mati tidak memiliki upah, Upah berasal dari kata " רכש: (sakar)"15 yang berarti sewa atau gaji. kata ini memiliki kasus noun common masculine singular absolute homonym ${ }^{16}$. Ini adalah bentuk kata benda berjenis kelamin maskulin tunggal yang berbentuk mutlak. Artinya membiayai, menggaji, membayar, dan memberikan harapan dari apa yang dikerjakan. Dalam terjemahan BIS diartikan sebagai "imbalan", sedangkan dalam TL diartikan "pahala" upah secara umumnya adalah seseorang yang dipekerjakan dan layak mendapatkan gaji berupa uang atau materi yang lainnya. Sebagai contoh seorang karyawan yang bekerja disalah satu perusahaan dan perusahaan wajib membayar karyawan dengan upah yang sesuai dengan apa yang dikerjakan. secara harafianya adalah bahwa orang yang sudah mati tidak mendapatkan kesempatan lagi untuk menerima upah. "Manusia yang hidup dapat menerima upah, yaitu sedikit keuntungan dari hasil kerja kerasnya di bumi, sementara sekadar kenangan sekalipun kepada orang mati tidak ada lagi". ${ }^{17}$ Lebih jelasnya bahwa setiap orang yang tidak hidup secara jasmani tidak akan menerima sama sekali upahnya baik itu gaji, maupun uang dari jeri payahnya selama dia masih hidup. Dapat diartikan bahwa orang yang sudah mati tidak lagi mendapat upah atau imbalan dalam bentuk apapun. Termasuk penghargaan dan penghormatan atau pembalasan jasa selama hidup orang tersebut. Orang yang hidup itu umumnya sungguh tidak memiliki banyak, tetapi orang yang sudah mati sama sekali tidak memiliki pahala, yakni upah. Seandainya semasa hidupnya mereka memiliki sesuatu, dari situlah tiada tersisi bagi mereka, bahkan ingataningatan merekapun tiada terpelihara. ${ }^{18}$ Dengan demikian penulis berpendapat bahwa orang yang sudah mati secara jasmani tidak lagi memiliki upah, imbalan, pahala dalam bentuk apapun. Karena orang yang sudah mati tidak lagi memiliki kenangan bahkan ingatan merekapun sudah tidak adalagi.

Orang hidup masih jauh lebih baik daripada orang mati dan inilah kebenaran yang tidak dapat disangkal. Orang Yahudi di dalam sejarah kehidupan mereka seringkali mengalami perlakukan tidak baik dari dunia, bukannya membenci kehidupan (seperti pernah dikatakan oleh Kohelet sendiri), tetapi mencintai kehidupan di atas segala-galanya. Maut dan kekuatannya tidak dapat membuat orang kapok dengan kegairahan hidup. Orang mati tidak tau apa-apa lagi, tidak menerima sakar, gaji/upah, bayaran, bagian dan tidak ada

\footnotetext{
${ }^{15}$ Spiros Zodhiates, The Hebrew-Grek Key Study Bible, “07939” hal, 116 (Amerika : World Bible Publisher, Inc, 1988 ), 824.

${ }^{16}$ Bible work 7, Pengkhotbah 9:5, 11/09/2019

${ }^{17}$ Robert Laurin, The WYCLIFFE Bible commentary, Kitab Pengkhotbah (Malang: Gandum MAS, 2007), 387.

${ }^{18}$ F.K.N. Harahap, Tafsiran Kitab Pengkhotbah, (Jakarta:BPK Gunung Mulia, 1975), 118.
} 
lagi kemenangan terhadap mereka. Kita mengubur orang mati untuk melupakan mereka. ${ }^{19}$ Hal tersebut menunjukkan tidak ada lagi aktivitas 'memberikan benda-benda materi' atau 'jasa' kepada orang mati.

\section{Orang Mati Tidak Tau Apa-Apa}

Pengkhotbah Pasal 9:5b menjelaskan bahwa, "orang mati tidak tahu apa-apa".

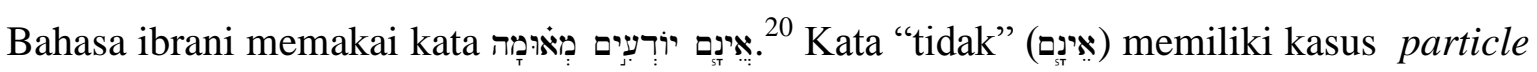
adverb negative $3 r d$ person masculine plural (not, do not). ${ }^{21}$ Merupakan kata keterangan yang bersifat negatif dan merujuk kepada orang ke-3 tunggal. Jadi artinya "mereka tidak". Sedangkan kata "tahu” (יוֹדִיִים) "yodayim" memakai kasus verb qal participle masculine plural absolute. ${ }^{22}$ Merupakan kata kerja partisipasi dengan jumlah jamak dan bersifat mutlak. Jadi kata "tahu" merupakan sebuah tindakan yang sungguh-sungguh diketahui oleh setiap orang.

Kata "apa-apa" (מְאוֹמָה) "meomah" memakai kasus noun common masculine singular absolute (nothing, anything). ${ }^{23}$ Merupakan kata benda yang bersifat umum dengan jumlah tunggal dan kata ini bersifat mutlak. Jadi kata "apa-apa" ini merujuk kepada sebuah prinsip benar-benar tidak ada, dan tidak bisa diganggu gugat lagi. berdasarkan kajian di atas penulis berpendapat bahwa, pengetahuan yang dimiliki oleh "orang mati” benar-benar tidak akan ada lagi. Dalam TL diartikan sebagai "tetapi orang yang sudah mati itu tidak tahu apa-apa", 24

Jadi orang yang sudah mati secara jasmani maka pengetahuannya pun akan mati yaitu tidak tau apa-apa lagi dan sama sekali tidak ada yang diingat olehnya atau mereka tidak mengerti apa-apa. Segala sesuatu yang berhubungan dengan animisme, kuasa gelap sangat bertentangan dengan Allah apalagi jika dikaitkan dengan tradisi yang berhubungan dengan orang mati. Karena Allahlah yang sesungguhnya patut menerima kemuliaan dan penghargaan serta penghormatan. Karena Allahlah yang menjadikan segala sesuatunya, dan karena kedaulatannya sajalah semuanya jadi. Dalam bukunya, Sproul mengatakan:

"pada waktu kita berbicara tentang kedaulatan Allah, itu berarti kita sedang berbicara tentang otoritas Allah dan kuasa Allah. Sebagai Allah

\footnotetext{
${ }^{19}$ Emanuel Gerit Singgih, Sebuah Tafsiran Pengkhotbah, (Jakarta: BPK Gunung Mulia, 2009), 169170.

${ }^{20}$ Bible Work.

${ }^{21}$ John Joseph owens, Analytical Key Old Testament, (America: Baker Boks House, 1993), 636.

${ }^{22}$ Reinhard Achenbach, Kamus Ibrani Indonesia Perjanjian Lama, (Jakarta: Yayasan Komunikasi Bina Kasih, 2011), 128.

${ }^{23}$ John Joseph owens, Analytical Key Old Testament, 636.

${ }^{24}$ Alkitab dalam versi Terjemahan Lama.
} 
yang berdaulat, Allah mempunyai otoritas yang tertingi atas langit dan bumi. Semua otoritas lain berada di bawah otoritas Allah dan bergantung pada otoritas Allah. Segala bentuk otoritas yang ada terjadi oleh karena diperintahkan atau diijinkan oleh Allah",25

Dari kutipan di atas, Allah sajalah yang mempunyai otoritas pada setiap ciptaanNya. Demikian juga dengan semua kuasa yang ada yang ada dalam alam semesta ini, semua itu berasal dari kuasa Allah.

Semua kuasa yang ada dalam alam semesta ini berada di bawah kuasa Allah (termasuk kuasa setan). Setan tidak berkuasa melakukan apa-apa kalau kedaulatan Allah tidak memberi ijin kepada setan untuk bertindak. ${ }^{26}$ Namun karena kehendak bebas yang dimiliki oleh manusia, akhirnya manusia dengan bebas juga melakukan tindakan sendiri yang membuat diri berdosa. Seharusnya manusia menjaga hubungan yang baik, karena Manusia berhubungan dengan Allah, manusia berhubungan dengan diri, manusia berhubungan dengan sesama, berhubungan dengan makhluk dan materi. Dalam bukunya, Stephen Tong mengatakan:

Semua hubungan seharusnya memiliki keseimbangan, seharusnya kita berelasi dengan Allah, mengasihi Allah, seharusnya kita mengerti Dia, taat kepada Dia. Kita seharusnya mengerti siapa setan, berani menolak dia dan tidak mau berdekatan dengan dia. Kita seharusnya tau bagaimana harus berelasi dengan Allah dan bagaimana harusnya berelasi dengan diri sendiri dan berelasi dengan sesama manusia lainnya. Semua ini memerlukan pikiran dan kuasa dari Roh Kudus. ${ }^{27}$

Dari kutipan diatas penulis berpendapat bahwa seharusnya manusia mampu membangun relasi yang baik dengan Allah, sesama, dan sebagainya, namun hal penting yang dilakukan adalah melibatkan Roh Kudus. Dengan melibatkan pekerjaan dari Roh Kudus maka manusia dapat menjalin relasi yang baik. Oleh sebab itu, Kristuslah yang mampu mempersatukan segala sesuatu dengan kasih Kristus sendiri.

Dalam poin ini penulis berpendapat, bahwa sebenarnya orang yang sudah mati sama sekali tidak lagi tau apa-apa, bahkan ketika sudah mengalami kematian secara jasmani maka saat itu juga orang yang telah mati tersebut tidak lagi memiliki kenangan, memori dan memang sama sekali tidak tau apa-apa lagi, termasuk perjuangan yang telah dilakukan oleh keluarg. Hal ini dipahami dalam konteks relasional aktivitas antara orang yang sudah mati dan yang masih hidup. Secara teologis orang yang mati rohnya pun tetap memiliki kesadaran namun secara konteks relasional 'tidak ada hubungan dengan

\footnotetext{
${ }^{25}$ R.C. Sproul, Kaum Pilihan Allah, (Malang, literaratur SAAT, 2003), 15

${ }^{26}$ Ibid.., 18

${ }^{27}$ Stephen Tong, Yesus Kristus Juru Selamat Dunia, (Surabaya: Momentum, 2005), 47
} 
orang yang hidup'. Tidak adanya ingatan tersebut diposisikan pada fisik orang yang mati, bukan di luar fisiknya. Karena jika di luar fisik maka masih ada ingatan yang dapat kita temukan dari orang mati, contoh: John Calvin sudah mati, tetapi ingatannya masih tetap ada, karena ia menuliskan apa yang menjadi ingatannya di dalam buku, sehingga dari segi ini ingatan orang mati masih ada.

\section{Orang Mati Tidak Akan Muncul Kembali}

Dalam Ayub 7:9 menjelaskan bahwa orang mati tidak akan muncul kembali, kata muncul berasal dari kata עלה (alah $)^{28}$ yang berarti, untuk naik, maju, menemui, mengunjungi, tidak ada lagi. Dengan kasus verb perfect $3 r$ person masculine singular ${ }^{29}$ Kata ini merupakan kata kerja yang berbentuk perfect yaitu suatu perbuatan yang sudah terjadi dan kata ini merujuk kepada orang ke tiga tunggal. Artinya, ketika kematian itu sudah terjadi (perfect) maka dia (orang mati itu) tidak akan hidup kembali. Dalam terjemahan BIS diartikan sebagai tak akan kembali pulang. Sedangkan dalam. Dalam TL tiada ia naik pula dari dalamnya. Artinya orang yang sudah mati dan yang sudah kembali ke tanah tidak akan muncul kembali ke muka bumi.

Dari kajian eksegese diatas, penulis berpendapat bahwa orang yang sudah tidak memiliki nafas hidup dapat dikatakan yang sudah mati secara tubuh jasmani tidak akan lagi hidup sama seperti manusia yang masih hidup dan tidak akan muncul lagi dan tidak akan hidup seperti dulu dia hidup. Mereka sudah menjadi bagian dunia orang mati dan tidak akan muncul dikehidupan orang yang masih hidup. Yang paling ditekankan dalam konteks ini adalah bahwa kehidupan yang dijalani orang hidup tidak akan ada lagi tak kalah manusia itu sudah turun kedalam kubur dan akan bersama-sama dengan orang yang sudah mati untuk selama-lamanya.

Dalam buku tafsiran yang ditulis oleh Atkinson mengatakan orang yang sudah mati seperti hembusan nafas, segumpalan awan yang melayang hilang, hidupnya telah menjadi kosong seperti uap dan ini adalah kalimat yang menujuk ke dunia orang mati di Syeol, dimana semuanya akan binasa selama-lamanya. ${ }^{30}$ Melalui poin ini penulis berpendapat bahwa orang yang sudah meninggal yang tidak memiliki nafas, mereka bagaikan uapan air atau hembusan nafas yang hilang dan tidak akan kelihatan lagi serta tidak akan tau apa-apa lagi. Pendapat berbeda diberikan dalam memahami istilah dunia orang mati, yaitu

\footnotetext{
${ }^{28}$ Spiros Zodhiates, The Hebrew-Grek Key Study Bible, “05927” hal, 88 (Amerika : World Bible Publisher, Inc, 1988 ),672

${ }^{29}$ Bible work 7, Pengkhotbah 9:5, 11/09/2019

${ }^{30}$ David Atkinso, Ayub dalam kasih Allah Rahasia Penderitaan, Tujuan, dan Kekuatananya ditemukannya, (Jakarta: Yayasan Komunikasih Bina Kasih, 1994), 94.
} 
keberadaan orang yang mati sudah ditentukan, yaitu yang mati di dalam Tuhan di Surga dan yang mati di luar Tuhan di neraka, dan tidak terjadi perpindahan tempat, sampai kedatangan Tuhan Yesus yang kedua kali. Jadi meskipun ada perbedaan pandangan namun ada kesamaan antara keduanya yaitu orang mati tidak bisa kembali ke dunia orang hidup, kecuali kasus tertentu yang dikehendaki oleh Allah sendiri.

\section{Orang Mati Tidak Akan Hidup Lagi}

Dalam Yesaya 26:14 dikatakan "Mereka sudah mati, tidak akan hidup pula, sudah menjadi arwah, tidak akan bangkit pula; sesungguhnya, Engkau telah menghukum dan memunahkan mereka, dan meniadakan segala ingatan kepada mereka." Kata tidak ini dalam KBBI yaitu partikel untuk menyatakan pengingkaran, penolakkan dan penyangkalan. Sedangan kata "tidak akan hidup" dalam bahasa aslinya adalah יוקיז ${ }_{2}^{31}$ dengan memakai kasus particle adverb verb qal imperfect 3 rd person masculine plural (the will not live) yang artinya "mereka tidak akan hidup" 32 merupakan kata keterangan berbentuk negatif "tidak" dari kata mereka tidak akan hidup.

Dari perbandingan diatas penulis berpendapat bahwa orang yang sudah mati tidak akan hidup kembali, dan sungguh tidak ada kepastian hidup mereka sudah menjadi arwah, dan arwah itu takkan ada lagi harapan untuk bangkit menjadi tubuh yang hidup. orang yang sudah mati atau orang yang telah meninggal dunia mereka tidak berhak dan memperoleh serta tidak mendapatkan kehidupan yang secara jasmani. Yang dimaksudkan disini bukan mati secara rohani, melainkan tubuh yang mengalami kematian. Yesaya sendiri menegaskan dalam nyanyiannya dimana kelepasan dan penghakiman yang diberikan Allah. Dalam bukunya tafsiran kitab Yesaya, Widyapranawa mengatakan:

Tuan-tuan itu kini sudah benar-benar mati dan kuasa mereka telah berakhir untuk selama-lamanya. Mereka telah menjadi arwah dan tidak bisa bangkit lagi. Kalimat ini tidak dimaksudkan untuk membicarakan tidak ada kebangkitan orang mati, seperti yang diajarkan oleh orang-orang saduki (Mrk 12:18). Yang dimaksud di sini hanya arwah-arwah itu tidak lagi berkuasa kembali untuk mengganggu orang beriman. Umat yang percaya tidak perlu lagi takut lagi terhadap arwah yang telah mati itu, karena Tuhan sesungguhnya telah menghukum dan memunahkan mereka, bahkan segala ingatan kepada arwah-arwah itupun akan ditiadakan. ${ }^{33}$

Penulis berpendapat bahwa arwah-arwah orang yang sudah mati sama sekali tidak memiliki hubungan dengan orang yang hidup, tidak lagi membutuhkan penghargaan atau

\footnotetext{
${ }^{31}$ John Joseph Owens, Analytical Key Old Testament, (Amerika: Baker Book House, 1993), 74.

${ }^{32}$ Spiros Zodhiates, The Hebrew-Grek Key Study Bible, "02421” hal, 88 (Amerika : World Bible Publisher, Inc, 1988 ), 858.

${ }^{33}$ S.H. Widyapranawa, tafsiran Kitab Yesaya, (Jakarta: BPK Gunung Mulia, 2010), 173.
} 
penghormatan, karena mereka tidak lagi hidup seperti yang dilakukan oleh orang-orang yang belum percaya yang biasa "memperingati" (menghormati dan menyenangkan) arwah- arwah itu dengan macam-macam upacara kultus pada hari-hari tertentu.

Allah tidak meninggalkan perbuatan tangan-Nya (Mzm 138:8), ia sedang menanggung segala sesuatu oleh Firman kekuatan-Nya (Ibr 1:3). Ia memelihara serta memerintah dunia ini berdaulat adanya. Bahwa Ia Transenden terhadap segala yang dijadikan-Nya. Bukan hanya Transenden, tetapi juga Imanen artinya bahwa Ia tinggal beserta dan bekerja di dalam dunia ini. ${ }^{34}$ Penulis berpendapat bahwa segala sesuatunya adalah kedaulatan Allah dimana tidak ada yang dapat terjadi tanpa kontrol Allah.

Dalam peristiwa pemindahan tulang Yusuf, ketika Yusuf mati, yang memberkati bangsa Israel bukan Yusuf walaupun Yusuf telah menjadi orang yang dipercaya di bangsa Mesir pada saat itu, Yusuf tidak mampu memberikan jaminan akan memberkati bangsa Israel Setelah ia mati. Namun yang benar ialah Allahlah yang akan memberkati bangsa Israel, sampai keluar dari perbudakan di tanah mesir.

Menurut konteks Yesaya ini, Penulis berpendapat bahwa orang mati memang sama sekali tidak akan hidup kembali dan tidak ada kepastian untuk hidup lagi, serta tidak memiliki tempat hidup dibumi. Seperti pada poin sebelumnya yang mengatakan bahwa orang yang telah mati tidak akan hidup kembali, karena orang yang telah mati secara jasmani tubuhnya akan kembali ke debu tanah sementara roh orang yang mati dalam Tuhan akan kembali kepada Allah dan roh yang mati di luar Tuhan akan berada di neraka.

\section{Perbedaan Orang Yang Mati Di Dalam Tuhan Dan Yang Mati Di Luar Tuhan}

Pada bagian ini penulis akan memaparkan perbedaan antara orang yang mati di dalam Tuhan dengan orang yang mati di luar Tuhan, Dalam 1 Tesalonika 4:14 mengatakan "yang meninggal dalam Yesus akan dikumpulkan bersama dengan Dia". Kata telah

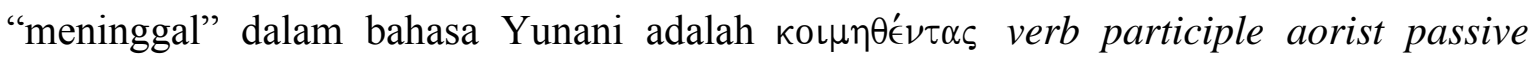
accusative masculine конаш koimao, yang artinya adalah kematian, orang yang tertidur (meningggal/mati) kata ini adalah partisif kata kerja yang pasif jantan. Ini bentuk kata yang menyatakan suatu kejadian untuk selamanya. Artinya orang yang sudah meninggal itu terjadi hanya satu kali untuk selamanya. Dengan kata lain orang yang sudah tidak ada lagi, tidak akan hidup kembali sama seperti orang yang masih hidup. Sedangkan kata "dalam Yesus" dalam bahasa Yunaninya adalah $\boldsymbol{\delta} \mathbf{\imath} \boldsymbol{\alpha}$ (dia) yang berkasus preposition genitive ini adalah kata yang menunjukan kepada kepemilikan atau kepunyaan yang

\footnotetext{
${ }^{34}$ G.C. Van Niftrik, Dogmatika Masakini, (Jakarta: BPK, 1967), 97
} 
artinya adalah melalui/sampai. Dari kajian eksegese di atas penulis menyimpulkan bahwa orang yang sudah mati dalam Yesus, akan menjadi milik Yesus sendiri apabila orang yang mati itu percaya kepada Yesus. Kalau dilihat dari kata akan di sini adalah menunjukan sesuatu yang terjadi nanti atau kata yang berakibat.

Allah akan membawa serta-Nya semua orang percaya yang sudah mati. Itulah sebabnya setiap orang yang percaya bahwa Yesus telah mati dan bangkit, mereka akan hidup bersama dengan Dia. Dalam NKJV "For if we believe that Jesus died and rose again, even so God will bring with Him those who sleep in Jesus". Artinya meskipun demikian Tuhan akan membawa dengan Nya, mereka yang tidur di dalam Yesus. Ayat ini tidak bisa dipahami bahwa jiwa tertidur setelah kematian. Istilah tidur dipahami adalam konteks ketiadaan aktivitas bagi fisik yang tanpa roh. Karena setelah kematian roh / jiwa telah ditentukan ke surga atau neraka.

Dapat diartikan bahwa orang yang sudah meninggal yang percaya kepada Tuhan sudah bersama dengan Yesus karena kita percaya bahwa Yesus sudah mati dan sudah bangkit lagi, itulah yang membuktikan bahwa orang yang sudah mati akan hidup kembali namun hidup mereka bukan hidup seperti waktu mereka masih hidup akan tetapi mereka sudah menjadi hak kepunyaan Yesus. Orang yang sudah mati namun percaya kepada Kristus ada bersama-sama dengan-Nya, begitu juga dengan sebaliknya orang yang mati namun tidak percaya kepada Kristus menderita sengsara di dalam neraka. Dengan demikian, hanya ada dua tempat bagi orang yang sudah mati secara jasmani, yaitu surga atau neraka. Dengan demikian tidak ada tempat ketiga atau bahkan dibumi pun bukanlah tempat roh lagi.

Selain itu Lukas 16:23 juga menjelaskan bagaimana keadaan orang yang sudah mati, dalam hal ini penulis juga akan memaparkan dalam konteks ini ada perbandingan tempat antara orang yang mati dalam Tuhan ( orang percaya) dan orang yang mati namun tidak mati di dalam Tuhan. Lazarus yang selama hidupnya takut akan Tuhan berada di pangkuan Abraham, sedangkan orang kaya yang sombong tersebut menderita di alam maut, Orang yang mati bukan didalam Tuhan dia mengalami penderitaan sengsara. Kata "menderita sengsara" dalam bahasa Yunani adalah $\beta \alpha \sigma \alpha v o s$ (basanos) yang berkasus noun dative feminine plural yang artinya adalah berkasus datif kata benda yang feminim jamak (lebih dari satu) yang memiliki pengertian siksaan. Ini adalah suatu objek tidak langsung, hanya

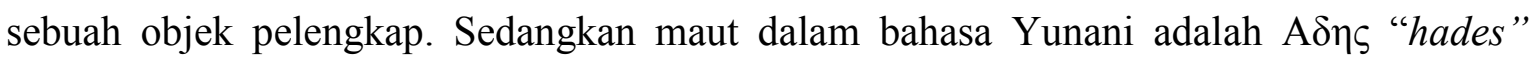
yang artinya dunia orang mati. Dapat diartikan bahwa orang yang mati di luar Tuhan dia akan mengalami siksaan di dalam maut atau tinggal di dunia orang mati yang penuh 
dengan penderitaan. Tubuhnya dikuburkan dan rohnya masuk ke Neraka untuk di siksa dalam api Neraka bersama dengan roh yang lainnya. Neraka ini menggambarkan dunia orang yang tidak hidup di dalam Tuhan (dunia orang mati).

Sedangkan orang yang hidup didalam Tuhan mereka tinggal bersama dengan Tuhan serta menikmati semua kebaikan Tuhan dalam Hidup mereka. Roh orang yang sudah mati masing-masing memiliki tempat tinggalnya dan sama sekali tidak ada peluang untuk bersatu dengan orang yang masih hidup, bukan hanya dengan orang yang hidup bahkan orang yang sama-sama telah matipun tidak memiliki hubungan sama sekali seperti peristiwa Lazarus yang takut akan Tuhan yang duduk dipangkuan Abraham dan orang kaya yang setelah matinya di alam maut.

Injil menegaskan bahwa tidak ada hubungan antara orang yang hidup dengan roh orang yang sudah mati. Ketegasan ini dapat dilihat dari pengajaran yang Tuhan Yesus berikan, didalam kisah Lazarus dengan orang kaya (Luk 16: 19-31). Setelah kematian hanya ada dua tempat yang diperuntukkan bagi manusia, satu di sorga (pangkuan Abraham, Mat 8:11), dan satu lagi dialam maut, suatu tempat penampungan sementara bagi orang yang tidak percaya kepada Yesus menjelang pengadilan akhir zaman. Tidak ada perpindahan manusia kedalam alam maut ataupun perpindahan dari alam maut ke sorga. ${ }^{35}$ Karena tidak ada hubungan antara manusia yang hidup dengan roh orang yang sudah mati, maka segala bentuk aktivitas manusia dikuburan yang berhubungan dengan roh orang mati adalah dosa dan kesia-siaan dihadapan Tuhan. Lagipula alkitab sudah mewaspadakan kita untuk tidak melakukan hal seperti itu. ${ }^{36}$

Dengan demikian hanya ada dua tempat bagi orang yang sudah mati, tidak ada selain itu, orang yang mati dalam Tuhan akan bersama-sama dengan-Nya, akan tetapi orang yang mati di luar Tuhan akan berada di alam maut. Bahkan roh orang matipun tidak memiliki kesempatan untuk berkomunikasi dengan manusia.

\section{PENUTUP}

Dalam pandangan Alkitab, tentang orang yang sudah mati, bahwa orang yang sudah mati sama sekali tidak tau apa-apa lagi dan tidak akan muncuk kemuka bumi dengan tegas mengatakan bahwa orang yang sudah mati rohnya tidak adalagi dibumi melainkan sudah memiliki tempat tersendiri, dalam kebenaran firman Tuhan mengatakan bahwa jiwa

\footnotetext{
${ }^{35}$ Hendry James Silalahi, Pandangan Injil terhadap Upacara Adat Batak..., 164.

${ }^{36}$ Ibid..,
} 
orang yang sudah mati namun semasa hidupnya percaya kepada Kristus, ia akan bersamasama dengan Kristus pula. Sementara jiwa orang yang sudah mati namun semasa hidupnya ia tidak percaya kepada Kristus, maka rohnya akan berada di dunia maut. Artinya tidak ada tempat ketiga dapat diartikan sebagai (bumi) bagi roh orang yang sudah mati. Itulah sebabnya menghormati orangtua haruslah semasa hidupnya bukan sewaktu matinya karena ketika orang tua sudah meninggal, dia bahkan tidak tau apa-apa lagi, dan tidak akan menikmati apa yang telah disediakan oleh keluarga atau anak-anaknya. Karena rohnyapun sudah tidak ada lagi dibumi. Secara keseluruhan dari pokok pembahasan yang ada, penulis mendapat kesimpulan :

Pertama, Pemindahan Tulang Yusuf adalah bukti iman Yusuf kepada Allah dimana Allah sendiri akan memelihara Bangsa Israel sampai keluar dari tanah Mesir, dan sesuai dengan permintaan Yusuf bahwa ketika sudah meninggal, tulang-belulangnya juga dibawa, hal ini meyakinkan Bangsa Israel supaya tidak takut akan hidup mereka ketika Yusuf mati. Dalam hal ini, pemindahan tulang-belulang Yusuf tidak menggunakan tradisi atau ritual-ritual yang berkaitan dengan nenek moyang atau roh leluhur. Secara jelas Alkitab tidak melarang pemindahan tulang bahkan tidak menganjurkan pemindahan tulang.

Kedua, pemahaman yang benar akan Firman Tuhan adalah dasar untuk setiap orang mengetahui hal yang benar dan hal yang salah. Menghormati orang tua haruslah semasa hidupnya bukan sesudah matinya, karena orang yang hiduplah yang dapat menikmati penghargaan, penghormatan, dan bukti kasih sayang dari seorang anak. Karena jikalau sudah mati, orangtua yang sudah meninggal tidak lagi dapat merasakan, tidak tau apa-apa lagi, bahkan tidak dapat merasakan kehidupan selayaknya manusia.

Ketiga, sebagai orang percaya iman kepada Kristus adalah dasar keselamatan, dan orang-orang yang telah diselamatkan pastilah memahami firman Tuhan dengan benar, hal demikian adalah hal yang paling utama, dengan demikian firman Tuhan sebagai pegangan supaya tidak terpengaruh kepada pemahaman yang salah serta mengubah pandangan yang salah dan yang bertentangan dengan Alkitab. Firman Allah lebih tinggi dari tradisi, oleh sebab itu setiap orang yang lebih mengutamakan tradisi sama halnya menduakan Tuhan.

Dengan demikian konsep tradisi kematian umat Israel, harus dilakukan pengakajian secara teologis. Karena ada hal-hal praktis yang tidak sama dengan konteks masa kini. Namun hal-hal prinsip tentang konsep kematian tetap dijaga, namun perlu penerangan dalam $\mathrm{PB}$, sehingga prinsip tersebut semakin terang maknanya. 


\section{DAFTAR PUSTAKA}

.... (). Alkitab Terjemahan Baru, Jakarta: LAI.

Achenbach, Reinhard. (2011). Kamus Ibrani Indonesia Perjanjian Lama, Jakarta: YKBK.

Atkinso, David. (1994). Ayub dalam kasih Allah Rahasia Penderitaan, Tujuan, dan Kekuatananya ditemukannya, Jakarta: YKBK.

Baker, F.L. (2002). Sejarah Kerajaan Allah, Jakarta: BPK Gunung Mulia.

Bible work 7, CD-ROM

Douglass, J.D. (1997). Ensiklopedi Masa Kini Jilid II, Jakarta: YKBK.

Harahap, F.K.N. (1975). Tafsiran Kitab Pengkhotbah, Jakarta: BPK Gunung Mulia.

Kelly, Page H. (2013). Pengantar Tata Bahasa Ibrani Biblikal, Surabaya: Momentum.

King, Philip J. (2010). Kehidupan Orang Israel Alkitabiah, Jakarta: BPK Gunung Mulia.

Laurin, Robert. (2007). Kitab Pengkhotbah, The Wycliffe Bible commentary, Malang: Gandum MAS.

Niftrik, G.C. Van. (1967). Dogmatika Masa Kini, Jakarta: BPK.

Owen, John Joseph. (1993). Analytical Key Old Testament, Amerika: Baker Books House.

Park, Abraham. (2017). Pertemuan Yang Terlupakan, Depok: Yayasan Damai Sejahtera.

Silalahi, Hendry James. (2004). Pandangan Injil terhadap Upacara Adat Batak, Sumatra Utara: Yayasan Karya Misi Kasih.

Singgih, Emanuel Gerit. (2009). Sebuah Tafsiran Pengkhotbah, Jakarta: BPK Gunung Mulia.

Sproul, R.C. (2003). Kaum Pilihan Allah, Malang, Literaratur SAAT.

Tong, Stephen. (2005). Yesus Kristus Juru Selamat Dunia, Surabaya: Momentum.

Widyapranawa, S.H. (2010). Tafsiran Kitab Yesaya, Jakarta: BPK Gunung Mulia.

Zodhiates, Spiros. (1988). The Hebrew-Grek Key Study Bible, Amerika : World Bible Publisher. 